\title{
Evaluation of antibacterial and antifungal activity of root and root callus extracts of Trianthema decandra L.
}

\author{
Mohammadreza Radfar ${ }^{1}$, M. S. Sudarshana ${ }^{1}$, H. U. Kavitha ${ }^{2}$, S. Satish ${ }^{2}$ and M. H. Niranjan ${ }^{1 *}$ \\ ${ }^{1}$ Department of Studies in Botany, University of Mysore, Manasagangotri, Mysore- 570 006, Karnataka, India. \\ ${ }^{2}$ Department of Studies in Microbiology, University of Mysore, Manasagangotri, Mysore- 570 006, Karnataka, India.
}

Accepted 28 December, 2011

\begin{abstract}
Trianthema decandra L. root and root callus extracts of different solvents viz., petroleum ether, chloroform, ethyl acetate and ethanol were tested against both Gram positive and Gram negative bacteria and also against Fusarium spp. Root callus extract of chloroform and ethanol showed significant activity against Bacillus subtilis, B. cereus. Staphylococcus aureus, Staph. epidermis and also against the other spp. of Gram negative bacteria viz., Pseudomonas aeruginosa, Klebseilla pneumonia, Alcaligens faecalis, Proteus vulgaris Enterobacter aerogenes, Salmonella typhi, Salmonella tyhimurium, Salmonella paratyphi $A$ and Salmonella enterica subsp. enterica with a MIC of 3.12 to 12.50 $\mu \mathrm{g} / \mathrm{ml}$ when compared to root extract of chloroform, ethyl acetate and ethanol of Trianthema decandra. Root callus extract of chloroform, ethyl acetate and ethanol showed activity against Fusarium verticilliodes, $F$. anthophilum, $F$. oxysporum and $F$. proliferatum with a lowest MIC of $3.12 \mu \mathrm{g} / \mathrm{ml}$ when compared to root extract of Trianthema decandra. The result shows that antibacterial and antifungal activity was more in root callus extract than root extract.
\end{abstract}

Key words: Trianthema decandra, antibacterial and antifungal activity, petroleum ether, root callus extracts.

\section{INTRODUCTION}

Despite the existence of potent antibiotics, resistant or multi resistant strains are continuously appearing, imposing the need for a permanent search and development of new drugs. The increasing failure of chemotherapies and antibiotic resistance exhibited by pathogenic microbial infections agents have led to the screening of several medicinal plants for their potential antimicrobial activity (Alagesaboopathi, 2011). For centuries, plants have been used throughout the world as drugs and remedies for various diseases. These drugs serve as prototype to develop more effective and less toxic medicines (Sharma et al., 2009). However, due to the acquired resistance by pathogens, most of the antibiotics have become ineffective and despite of the tremendous progress in human medicines, infectious diseases caused by bacteria, fungi, viruses and parasites are still a major threat to public

${ }^{*}$ Corresponding author.

E-mail:

niranmhniran@gmail.com. Tel: +919449131751. health. Their impact is particularly large in developing countries due to relative unavailability of medicines and the emergence of widespread drug resistance (Zampini et al., 2009), along with appearance of undesirable side effects of certain antibiotics (Li et al., 2007; Amador et al., 2009) has lead to the search of new antimicrobial agents mainly among plant extracts with the goal to discover new chemical structures, which overcome the above diadvantages (Bouamama et al., 2006; Silbergeld et al., 2008).

Fungi cause severe damage to stored food commodities. Fungal diseases in agriculture crops pose a great challenge. Among different species of fungi, Aspergillus sp. and Fusarium sp. cause heavy losses to grains, fruits, foodstuffs and vegetables (Satish et al., 2007). The Fusarium species are generally considered to be field fungi and were thought to proliferate before harvest (Christensen et al., 1977). However, Fusarium species may also grow and produce mycotoxins under certain storage conditions. Alternative strategies have included the search for new types of pesticides which are 
often effective against a limited number of specific target species, are biodegradable into nontoxic products and are suitable for use in integrated pest management programs (Koul et al., 2008). The natural plant products derived from plants effectively meet this criterion and have enormous potential to influence modern agrochemical research. When extracted from plants, these chemicals are referred to as botanicals. The use of botanical pesticides is now emerging as one of the prime means to protect crops and their products and the environment from pesticide pollution.

In recent years, research on medicinal plants has attracted a lot of attentions globally. Large body of evidence has accumulated to demonstrate the promising potential of medicinal plants used in various traditional, complementary and alternate systems of treatment for both human and plant diseases. Plants growing in natural habitats are normally exposed to a broad range of microorganisms, many of which are pathogens or opportunists. However, they are able to resist microbial attack and depending on their tolerance toward a particular pathogen, they can continue to grow, overcoming the stress induced by the microbial action. The latter is possible, because plants have various physical and chemical strategies that allow them to defend themselves, the chemical mechanism being the most elective barrier against pathogens and herbivorous attacks (Broekaert et al., 1997). These active compounds can be inducible or preformed, and they can be grouped into two major classes: (1) antimicrobial proteins and (2) a wide variety of non-protein compounds or secondary metabolites. Plants are rich in a wide variety of secondary metabolites such as tannins terpenoids, alkaloids, flavonoids, etc, which have been found in vitro to have antimicrobial properties (Dahanukar et al., 2000; Cowan, 1999). Plants that possess antibacterial activity and can potentially be used to treat ailments brought about by bacterial infections and alleviate many of the associated symptoms. The belief that natural medicines are much safer than synthetic drugs has gained popularity in recent years and led to tremendous growth of phyto pharmaceutical usage.

Similarly in vitro derived callus can also synthesizes these compounds. Hence, in vitro culture is used as an alternative to whole plants for the production of useful secondary metabolites. The application of plant tissue and cell culture technique has been employed to investigate various controlling biosynthesis of medicinally important compounds. In some cases, yield in cell culture are many fold greater than those observed in the whole plant (Ammirato, 1987).

Trianthema decandra $\mathrm{L}$. is a prostrate, glabrous, succulent medicinal herb belonging to the family Aizoaceae. It is distributed in the tropical and subtropical regions of the world. The root of $T$. decandra is used for the treatment of hepatitis, asthma and orchitis, and also, the decoction of the root bark is credited with properties of aperients. The juice of the leaves dropped into the nostrils relieves one-sided headache (Warrier et al., 1994).
Resistance fungal pathogens and the emergence of new resistant human pathogens including environmental and health problems related to the use of chemical fungicides have in dictate the search for novel antifungal and antibacterial agents for human disease and plant protection.

The purpose of this study was to investigate the antimicrobial activity of root and root calls extract of $T$. decandra and its callus against human pathogenic bacteria and phytopathogenic fungi.

\section{MATERIALS AND METHODS}

\section{Plant material}

Roots of $T$. decandra were collected from Mysore, Karnataka, India. A voucher specimen of the plants has been deposited in the herbarium of Department of Studies in Botany, University of Mysore, Mysore, Karnataka, India

\section{Root callus}

Root callus were achieved on MS media supplemented with BAP $1 \mathrm{mg} / \mathrm{lt}+\mathrm{NAA} 0.5 \mathrm{mg} / \mathrm{lt}$.

\section{Preparation of solvent extracts}

Thoroughly washed mature roots and root callus were shaded dried and then powdered with the help of waring blender. Twenty-five grams of the powder was filled in the thimble and extracted successively with petroleum ether, chloroform, ethyl acetate and ethanol using a Soxhlet extractor for $48 \mathrm{~h}$. Like wise the same procedure was followed for root callus obtained from the roots of $T$. decandra. All the extracts were concentrated using rotary flash evaporator and preserved at $5^{\circ} \mathrm{C}$ in airtight bottles until further use.

\section{Human pathogenic bacteria}

Gram negative bacteria such as Escherichia coli (MTCC 7410), Pseudomonas aeruginosa (MTCC 7903), Klebseilla pneumonia (MTCC 7407), Alcaligens faecalis (MTCC 7416), Enterobacter aerogenes (MTCC 7325), Proteus vulgaris (MTCC 1771), Proteus mirabilis (MTCC 425), Salmonella typhi (MTCC 733), Salmonella enterica sub sp enterica (MTCC 3224), Salmonella paratyphi A (MTCC 735), Salmonella tyhimurium (MTCC 1254), and Gram positive bacteria such Staphylococcus aureus (MTCC 7443), Staphylococcus epidermis (MTCC 435), Bacillus subtilis (MTCC 121) and Bacillus cereus (MTCC 1272) were obtained from MTCC Chandighar, India.

\section{Plant pathogenic fungi}

Important seed-borne pathogenic field and storage fungi associated with maize seeds such as $F$. verticilliodes, $F$. anthophilum $F$. oxysporium and $F$. proliferatum were isolated and cultured for this present study.

\section{Antibacterial activity assay}

Trichlorotriphenyl Tetrazolium Chloride (TTC) method was 
Table 1. Minimal inhibitory concentration of different solvent extracts of root and root callus extracts of Trianthema decandra and chloramphenicol against gram positive bacteria.

\begin{tabular}{|c|c|c|c|c|c|}
\hline \multirow[b]{2}{*}{ Extract } & \multirow[b]{2}{*}{ Solvent } & \multicolumn{4}{|c|}{ Test pathogens (Gram positive bacteria, $\mu \mathrm{g} / \mathrm{ml}$ ) } \\
\hline & & $\begin{array}{c}\text { B. cereus } \\
\text { (MTCC 1272) }\end{array}$ & $\begin{array}{l}\text { B. subtilis } \\
\text { (MTCC 121) }\end{array}$ & $\begin{array}{l}\text { Staph. aureus } \\
\text { (MTCC 7443) }\end{array}$ & $\begin{array}{l}\text { Staph. epidermis } \\
\text { (MTCC 435) }\end{array}$ \\
\hline \multirow{4}{*}{ Root extract } & Petroleum ether & 12.50 & 12.50 & 12.50 & 12.50 \\
\hline & Chloroform & 25.00 & 50.00 & 25.00 & 25.50 \\
\hline & Ethyl acetate & 06.25 & 12.50 & 25.00 & 50.00 \\
\hline & Ethanol & 12.50 & 12.50 & 12.50 & 12.50 \\
\hline \multirow{4}{*}{ Callus root extract } & Petroleum ether & 12.50 & 06.25 & NA & NA \\
\hline & Chloroform & 03.12 & 03.12 & 03.12 & 06.25 \\
\hline & Ethyl acetate & 06.25 & 06.25 & 03.12 & 06.25 \\
\hline & Ethanol & 03.12 & 03.12 & 06.25 & 06.25 \\
\hline \multicolumn{2}{|c|}{ Chloramphenicol $1 \mathrm{mg} / \mathrm{ml}$} & 03.12 & 01.57 & 01.22 & 01.22 \\
\hline
\end{tabular}

Values are mean of triplicates, NA -no activity

determined by Sette et al. (2006) using Muller-Hinton Broth on a tissue culture test plate ( 96 wells) for bacterial cultures.

The stock solutions of the root and root callus extracts of $T$. decandra were diluted and transferred into the first well, and serial dilutions were performed in order to have concentrations in the range of 50 to $0.39 \mu \mathrm{g} / \mathrm{ml}$. Chloramphenicol was used as the reference antibacterial agent. The inoculum was added to all wells and the plates were incubated at $36^{\circ} \mathrm{C}$ for $48 \mathrm{~h}$. Antibacterial activity was detected by adding $0.5 \%$ TTC (Trichlorotriphenyl tetrazolium chloride, Merck) aqueous solution. MIC was defined as the lowest concentration of oil that inhibited visible growth, as indicated by the TTC staining (dead cells are not stained by TTC).

\section{Antifungal activity}

3-(4,5-Dimethyl-2-thiazolyl)-2,5-diphenyl-2H-tetrazolium bromide (MTT) assay tests were carried out according to Jahn et al. (1995) and Mosmann (1983) using tissue culture test plate (96 wells) for fungal cultures.

The fungal strains were grown at $28^{\circ} \mathrm{C}$ in potato dextrose broth (PDB) medium. The fungal cells were seeded in the wells of a 96microtiter plate in Potato Dextrose Broth media at a density of $2 \times$ $10^{-3}$ cells $(100 \mu \mathrm{l}$ per well). $10 \mu \mathrm{l}$ of the serially diluted extract was added to each well and the suspension was incubated for $24 \mathrm{~h}$ at $28^{\circ} \mathrm{C}$. $10 \mu \mathrm{l}$ of a 3 -(4, 5-dimethyl-2-thiazolyl)-2, 5-diphenyl-2Htetrazolium bromide (MTT) solution [5 mg/ml MTT in phosphate buffered saline (PBS), $\mathrm{pH}$ 7.4] was added to each well and the plates were incubated further at $37^{\circ} \mathrm{C}$. $30 \mu \mathrm{l}$ of $20 \%(\mathrm{w} / \mathrm{v})$ SDS solution containing $0.02 \mathrm{M} \mathrm{HCl}$ was then added and the plates were incubated at $37^{\circ} \mathrm{C}$ for $16 \mathrm{~h}$ to dissolve the formazan crystals that had formed. The turbidity of each well was measured at $570 \mathrm{~nm}$ using a microtitrator ELISA reader and observed for change in color. MIC was defined as the lowest concentration of extract that inhibited visible growth, as indicated by the MTT staining (dead cells are not stained by MTT). Bavistin was taken as a standard fungicide at a concentration of $0.5 \mathrm{mg} / \mathrm{ml}$.

\section{RESULTS}

Thianthema decandra L. root and root callus extracts of different solvents viz., petroleum ether, chloroform, ethyl acetate and ethanol tested for antibacterial activity chloroform and ethanol extracts of root callus showed significant activity against Gram positive bacteria particular on B. subtilis, B. cereus and Staph aureus when compared to the crude root extracts (Table 1). The result shows signifi-cant activity in root callus extract of $T$. decandra compared to the root solvent extract. Petroleum ether and ethanol extract of $T$. decandra showed an MIC of $12.5 \mu \mathrm{g} / \mathrm{ml}$ against all the Gram positive bacteria tested whereas $50 \mu \mathrm{g} / \mathrm{ml}$ crude cholorform extract and ethyl acetate was required to inhibit $B$. subtilis and Stap. epidermis, respectively. $T$. decandra root callus extract of chloro-form, ethyl acetate and ethanol showed significant inhibition at 3.12 to $6.25 \mu \mathrm{g} / \mathrm{ml}$ against the tested Gram positive bacteria. However, petroleum ether root callus extract showed much higher MIC around $12.50 \mu \mathrm{g} / \mathrm{ml}$ against all pathogen tested expect Stap. epidermis.

Root callus extract showed highly significant antibacterial activity against Gram negative bacteria then the crude root extract (Table 2). Root extract of petroleum ether showed a MIC of 25 to $50 \mu \mathrm{g} / \mathrm{ml}$ against all the Gram negative bacteria. Root extract of ethyl acetate and ethanol extract showed lowest MIC of 3.12 to $12.50 \mu \mathrm{g} / \mathrm{ml}$ when compared to petroleum ether and chloroform. No inhibitory activity was observed in petroleum ether root callus extract against Alcaligens faecalis, E. coli, Klebseilla pneumonia, Proteus vulgaris, Salmonella enterica sub sp. enterica, Salmonella paratyphi A, Salmonella typhi and Salmonella tyhimurium but inhibited all the other tested Gram negative bacteria at MIC of 50 $\mu \mathrm{g} / \mathrm{ml}$. Significant activity was observed in root callus extract of chloroform, ethyl acetate and ethanol with MIC of around 3.12 to $12.50 \mu \mathrm{g} / \mathrm{ml}$.

Thianthema decandra root and root callus extracts of different solvents viz., petroleum ether, cholorform, ethyl acetate and ethanol were tested for antifungal activity against $F$. verticilliodes, $F$. anthophilum, $F$. oxysporum and F. proliferatum. T. decandra root callus 
Table 2. Minimal inhibitory concentration of different solvent extracts of root and root callus extracts of Trianthema decandra and chloramphenicol against gram negative bacteria.

\begin{tabular}{|c|c|c|c|c|c|c|c|c|c|c|c|c|c|}
\hline \multirow{2}{*}{ Extract } & \multirow{2}{*}{ Solvent } & \multicolumn{12}{|c|}{ Test pathogens (Gram negative bacteria, $\mu \mathrm{g} / \mathrm{ml}$ ) } \\
\hline & & 1 & 2 & 3 & 4 & 5 & 6 & 7 & 8 & 9 & 10 & 11 & 12 \\
\hline & Petroleum ether & 50.00 & 25.00 & 50.00 & 25.00 & 25.00 & 25.00 & 50.00 & 25.00 & 25.00 & 50.00 & 25.00 & 50.00 \\
\hline \multirow[t]{5}{*}{ Root extract } & Chloroform & 25.00 & 12.50 & 25.00 & 25.00 & 50.00 & 12.50 & 12.50 & 25.00 & 25.00 & 25.00 & 25.00 & 25.00 \\
\hline & Ethyl acetate & 12.50 & 06.25 & 12.50 & 12.50 & 12.50 & 25.00 & 25.00 & 12.50 & 06.25 & 12.50 & 06.25 & 12.50 \\
\hline & Ethanol & 06.25 & 03.12 & 06.25 & 25.00 & 06.25 & 50.00 & 12.50 & 12.50 & 12.50 & 12.50 & 50.00 & 12.50 \\
\hline & Petroleum ether & NA & 50.00 & NA & NA & 50.00 & NA & 50.00 & NA & NA & NA & NA & 50.00 \\
\hline & Chloroform & 03.12 & 06.25 & 12.50 & 03.12 & 06.25 & 12.50 & 03.12 & 06.25 & 12.50 & 06.25 & 12.50 & 06.25 \\
\hline \multirow[t]{2}{*}{ Root callus extract } & Ethyl acetate & 06.25 & 03.12 & 06.25 & 03.12 & 06.25 & 03.12 & 06.25 & 06.25 & 12.50 & 06.25 & 12.50 & 03.12 \\
\hline & Ethanol & 12.50 & 03.12 & 12.50 & 06.25 & 03.12 & 12.50 & 12.50 & 06.25 & 03.12 & 06.25 & 06.25 & 12.50 \\
\hline \multicolumn{2}{|c|}{ Choramphenicol (1mg/ml) } & 03.12 & 03.12 & 01.57 & 1.22 & 01.57 & 1.22 & 01.57 & 1.22 & 1.22 & 01.57 & 01.57 & 01.57 \\
\hline
\end{tabular}

Values are mean of triplicate; NA :no activity (1) Alcaligens faecalis (MTCC 7416); (2) Enterobacter aerogens (MTCC 7325); (3) Escherichia coli (MTCC 7410); (4) Klebseilla pneumonia (MTCC 7407); (5) Proteus mirabilis (MTCC 425); (6) Proteus vulgaris (MTCC 1771); (7) Pseudomonas aeruginosa (MTCC 7903); (8) Salmonella enterica sub sp. enterica (MTCC 3224); (9) Salmonella paratyphi A (MTCC 735); (10) Salmonella tyhimurium (MTCC 1254); (11) Salmonella typhi (MTCC 733) and (12) Vibrio parahaemolyticus (MTCC 451).

Table 3. Minimal inhibitory concentration of different solvent extracts of root and callus root extract of Trianthema decandra and Bavistin against Fusarium spp.

\begin{tabular}{llcccc}
\hline \multirow{2}{*}{ Extract $(\mathbf{1 0 0} \boldsymbol{\mu l} / \mathbf{m l})$} & \multirow{2}{*}{ Solvent } & \multicolumn{3}{c}{ Test phytopathogenic $(\boldsymbol{\mu g} / \mathbf{m l})$} \\
\cline { 3 - 6 } & Petroleum ether & $\boldsymbol{F}$. verticilliodes, & $\boldsymbol{F}$. anthophilum, & $\boldsymbol{F}$. oxysporum & $\boldsymbol{F}$. proliferatum \\
\hline \multirow{3}{*}{ Root extract } & Chloroform & 06.25 & 25.00 & 06.25 & 12.50 \\
& Ethyl acetate & 06.25 & 06.25 & 06.25 & $\mathrm{NA}$ \\
& Ethanol & 12.50 & 12.50 & 06.25 & $\mathrm{NA}$ \\
& & & 06.25 & 06.25 & 06.25 \\
Callus root extract & Petroleum ether & $\mathrm{NA}$ & $\mathrm{NA}$ & $\mathrm{NA}$ & $\mathrm{NA}$ \\
& Chloroform & 03.12 & 03.12 & 03.12 & 03.12 \\
Bavistin $(0.5 \mathrm{mg} / \mathrm{ml})$ & Ethyl acetate & 03.12 & 03.12 & 03.12 & 03.12 \\
\hline
\end{tabular}

Values are mean of triplicate; NA: no activity.

extracts of chloroform, ethyl acetate and ethanol showed highly significant activity against all the tested Fusarium spp. with a lowest MIC of
$3.12 \mu \mathrm{g} / \mathrm{ml}$ when compared to root extract of $T$. decandra than with a MIC of 25.50 to $6.25 \mu \mathrm{g} / \mathrm{ml}$ (Table 3).
Antifungal activity was not observed in petroleum ether root callus extract against the tested Fusarium sp. T. decandra chloroform 
and ethyl acetate root extract did not show any activity against $F$. proliferatum. Bavistin showed complete inhibition even at a lowest concentration of $0.001 \mathrm{mg} / \mathrm{ml}$.

\section{DISCUSSION}

The history of medicine includes many ludicrous therapies. Nevertheless, ancient wisdom has been the basis of modern medicine and will remain as one important source of future medicine and therapeutics. The future of natural products drug discovery will be more holistic, personalized and involve wise use of ancient and modern therapeutic skills in a complementary manner so that maximum benefits can be accrued in the management of plant and human disease management. Lag phase for botanical medicine is now rapidly changing for a number of reasons. Problems with drug-resistant microorganisms, side effects of modern drugs, and emerging diseases where no medicines are available have stimulated renewed interest in plants as a significant source of new medicines.

Fungal deterioration of stored seeds and grains is a chronic problem in the Indian storage system because of the tropical hot and humid climate. The presence and growth of fungi may cause spoilage of food and its quality and quantity. In-spite of use of all available means of plant protection, about $1 / 3$ of the yearly harvest of the world is destroyed by pests, and loss due to this is expected to be nearly $\$ 300$ billion per year (Chandler, 2005). Today, there are strict regulations on chemical pesticide use, and there is political pressure to remove the most hazardous chemicals from the market (Pal and Gardener, 2006). Although, restrictions are being imposed to protect food quality and the environment, chemicals are still our only recourse at present to prevent diseases of food crops. In recent years, the need to develop disease control measures as alternative to chemicals has become a priority of scientists' worldwide (Reddy et al., 2009).

Traditional knowledge will serve as a powerful search engine and most importantly, will greatly facilitate intentional, focused and safe natural products research to rediscover the drug discovery process. The appeal of using natural products for medicinal purposes is increasing, and at present, researchers aim to produce substances with anti-tumor, anti-viral, hypoglycemic, antiinflammatory, anti-parasite, antimicrobial, tranquilizer and immune modulating activities through tissue culture technology. Advances in the area of cell cultures for the production of medicinal compounds has made possible the production of a wide variety of pharmaceuticals like alkaloids, terpenoids, steroids, saponins, phenolics, flavonoids, and amino acids (Singh, 2011).

The finding of this present investigation is an important step towards crop protection strategies for fungal disease management particularly caused by Fusarium sp., and also on human pathogens. Geethalakshmi et al. (2010) have given detailed account on $T$. decandra for its phyto- chemistry and various biological properties of the extract and the constituents might provide incentive for proper evaluation of the use of the plant in medicine. In this present study, callus extract of chloroform, ethyl acetate and ethanol extract showed highly significant activity when compared with crude extract. This tends to express that the active ingredients is an effective antibiotic and active principle or compound may be more in callus than in the roots of $T$. decandra. The results of this present study was successful in identifying the nature of the bioactive principle and its solubility which will help in further isolation and characterization of the active principle responsible for the activity for development of new antimicrobial agents for preventive treatment of serious microbial disease infections in both human beings and animals along with plant fungal diseases.

\section{ACKNOWLEDGEMENT}

The authors are grateful to the Department of Studies in Botany and Microbiology, University of Mysore, Manasagangotri, for laboratory facility.

\section{REFERENCES}

Alagesaboopathi C (2011). Antimicrobial screening of selected medicinal plants in Tamil nadu, India. Afr. J. Microbiol. Res. 5(6): 617-621.

Amador P, Fernandes R, Prudencio C, Brito L (2009). Resistance to Blactams in bacteria isolated from different types of Portuguese cheese. Int. J. Mol. Sci 10: 1538-1551.

Ammirato PV (1987). In Plant tissue and Cell Culture,(eds) Green C E,Somers DA, Hackett,WP., Biesboer,D.P., Alan,R., Liss Inc, New York, p. 57.

Bouamama H, Noel T, Villard J, Benharref A, Jana M (2006). Antimicrobial activities of the leaf extract of two Moroccan Cistus $L$ species. J. Ethnopharmacol. 5: 104-107.

Broekaert WF, Cammue BPA, Bolle MFC, Thevissen K, De Samblanx W, Osborn RW (1997). Antimicrobial peptides from plants. Crit. Rev. Plant Sci. 16: 297-323.

Christensen CM, Mirocha CJ, Meronuch RA (1977). Molds, mycotoxins and mycotoxicoses. Uni. of Minnesoto agr. Exp. Sta. Misc. Rep. 142: 1-11.

Cowan MM (1999). Plant products as anti-microbial agents. Clin Microbiol Rev. 12: 564-582.

Dahanukar SA, Kulkarni RA, Rege NN (2000). Pharmacology of medicinal plants and natural products. Indian J. Pharmacol. 32: 81118.

Geethalakshmi R, Sarada DVL, Marimuthu (2010). Evaluation of antimicrobial and antioxidant potential of Trianthema decandra. Asian J. Biotechnol. 2(4): 225-231.

Jahn B, Martin E, Stueben A, Bhakdi S (1995). Susceptibility testing of Candida albicans and Aspergillus species by a simple microtiter menadione-augmented 3-(4,5-dimethyl-2-thiazolyl)-2,5-diphenyl- $2 \mathrm{H}$ tetrazolium bromide assay, J. Clin. Microbiol. 33: 661-667.

Koul P, Walia S, Dhaliwal GS (2008). Essential oils as green pesticides: Potential and constraints. Biopesticides Int. 4(1): 63-84.

Li XZ, Mehrotra M, Ghimire S, Adewoye L (2007). B-lactam resistance and B-lactamases in bacteria of animal origin. Vet. Microbiol. 121: 197-214.

Mosmann T (1983). Rapid colorimetric assay for cellular growth and survival application to proliferation and cytotoxicity assays. $\mathrm{J}$. Immunol. Method. 65: 55-63.

Pal KK, Gardener BS (2006). Biological control of plant pathogens. The 
Plant Health Instructor. doi:10.1094/PHI-A-2006-1117-02.

Reddy KRN, Reddy CS, Muralidharan K (2009). Potential of botanicals and biocontrol agents on growth and aflatoxin production by Aspergillus flavus infecting rice grains. Food Cont. 20: 173-178

Satish S, Mohana DC, Raghavendra MP, Raveesha KA (2007). Antifungal activity of some plant extracts against important seed borne pathogens of Aspergillus sp. J. Agric. Technol. 3(1): 109-119.

Sette LD, Passarini MRZ, Delarmelina C, Salati F, Duarte MCT. (2006). Molecular characterization and antimicrobial activity of endophytic fungi from coffee plants, World J. Microbiol Biotechnol. 22: 11851195.

Sharma A, Chandraker S, Patel VK, Ramteke P (2009). Antibacterial activity of medicinal plants against pathogens causing complicated urinary tract infections. Indian J. Pharm. Sci. 71: 136-139.

Silbergeld EK, Graham J, Price LB (2008). Industrial food animal production, antimicrobial resistance and human health. Ann. Rev. Public Health, 29: 151-169.
Singh CR (2011). Antimicrobial effect of callus and natural plant extracts of Premna serratifolia L. Intl. J. Biomed. Pharma. 2(1): 17-20.

Warrier PK, Nambiar VP, Ramankutty C (1994). Indian medicinal plants a compendium of 500 species. vol. 1. India: Orient Longman Pvt Ltd. pp. 349-351.

Zampini IC, Cuello S, Alberto MR, Ordonez RM, Almeida RD, Solorzano E, Isla MI (2009). Antimicrobial activity of selected plant species from the Argentine puna against sensitive and multiresistant bacteria, J. Ethnopharm. 124: 499-505. 